\title{
Progesterone receptor expression and proliferative activity in relation to histological architecture of feline mammary fibroadenomatous change
}

\author{
MAGDALENA KRAWCZYK, WOJCIECH ŁOPUSZYŃSKI*, \\ MAREK SZCZUBIAK, YOLANDA MILLÁN**
}

\begin{abstract}
Department of Animal Reproduction, *Department of Pathological Anatomy, Faculty of Veterinary Medicine, University of Life Sciences in Lublin, Głęboka 30, 20-033 Lublin, Poland

**Department of Anatomy and Comparative Pathology, Faculty of Veterinary Medicine, University of Córdoba, Campus Universitario de Rabanales, Carretera Madrid - Cádiz Km, 396. 14071 Córdoba, Spain
\end{abstract}

Krawczyk M., Łopuszyński W., Szczubiał M., Millán Y.

Progesterone receptor expression and proliferative activity in relation to histological architecture of feline mammary fibroadenomatous change

\section{Summary}

The aim of the study was to determine the relationship between histological architecture and progesterone receptor expression as well as proliferative activity in feline mammary fibroadenomatous change (FMFAC) in female cats. The investigations were performed on 16 surgically removed FMFAC diagnosed based on their gross and microscopic appearance. The lesions were divided into 2 groups based on the number of epithelium layers: lesions with two or less ductal epithelium layers formed group A and lesions with more than two layers of epithelial cells were assigned to group B. Moreover, in each group the lesions were classified according to the cellularity of stroma into three subgroups (with poor, moderate and abundant cellularity). Immunohistochemical examinations were carried out to detect an expression of progesterone receptors (PRs) and a proliferative activity (based on Ki-67 antigen expression). The PR expression and Ki-67 antigen expression were significantly higher in epithelial cells than in stromal cells; however, the differences in above mentioned markers in ductal epithelium and stromal cells between studied groups were not significant. The results of this study indicate that there is no relationship between histological appearance, PR expression and proliferative activity in FMFAC. Moreover, a high percentage of PR-expressing cells in duct epithelium may explain the regression of enlarged mammary gland after administration of progesterone receptor blockers.

Keywords: feline mammary fibroadenomatous change, mammary tumors, progesterone receptor, Ki-67 antigen, immunohistochemistry

Feline mammary fibroadenomatous change (FMFAC) (also known as mammary hypertrophy, mammary hyperplasia, mammary dysplasia, fibroadenoma complex, fibroepithelial hyperplasia or fibroglandular mammary hypertrophy) is a non-neoplastic condition that was first described in 1973 (1). It is characterized by proliferation of interlobular ducts and periductal stromal cells of one or more mammary glands of young and adult queens $(7,29)$.

Clinically, FMFAC is characterized by a rapid and massive increase in size of one or multiple mammary glands, which appear swollen and tense $(14,20,34$, $35)$. The fibroadenomatous change is generally nonpainful, dome-shaped and firm. In some chronic cases the primary FMFAC may co-exist with mastitis or ulceration (2). Moreover, when severe swelling of the mammary glands develops, locomotor problems may arise (34).

Histologically, an increase in size of mammary glands is characterized by proliferation of ductal epithelial cells and marked oedema as well as increased amounts of connective tissue surrounding the glands (1, $20,35)$. The proportions of epithelial and connective tissue are variable within the lesion. The stroma can be loose, densely cellular and disorganized or less cellular, compact and collagenous, separating mammary lobules. The branching ductal structures are lined by two to several layers of cuboidal to columnar epithelial cells, in some cases with marked cellular atypia similar to that observed in atypical hyperplasia. Mitotic figures are commonly found both in the epithelium and the stroma $(1,13,27)$. The lesion is unique to the 
cat, although fibroepithelial tumors with stromal expansion and similar morphologic features occur in rats, rabbits and women $(11,19)$.

It is commonly accepted that progesterone and its synthetic derivates play an essential role in the development of FMFAC $(9,12,20,22,34$, $35)$. This condition usually occurs in cyclic and pregnant females, under the influence of endogenous progesterone $(9,15,32)$. It can also occur in female and male cats after administration of synthetic progestogens, such as medroxyprogesterone acetate, megestrol acetate or proligestone $(14,17,20,21,34)$. The fact that luteolysis, ovariectomy, spontaneous abortion or parturition generally are associated with spontaneous remission of the disease and complete regression of mammary enlargement demonstrate a key role of progesterone in development of FMFAC $(14,20)$. Moreover, biochemical and immunohistochemical studies have revealed an increased level of PRs in hyperplastic mammary glands of cats $(14,22)$. It was also found that the administration of

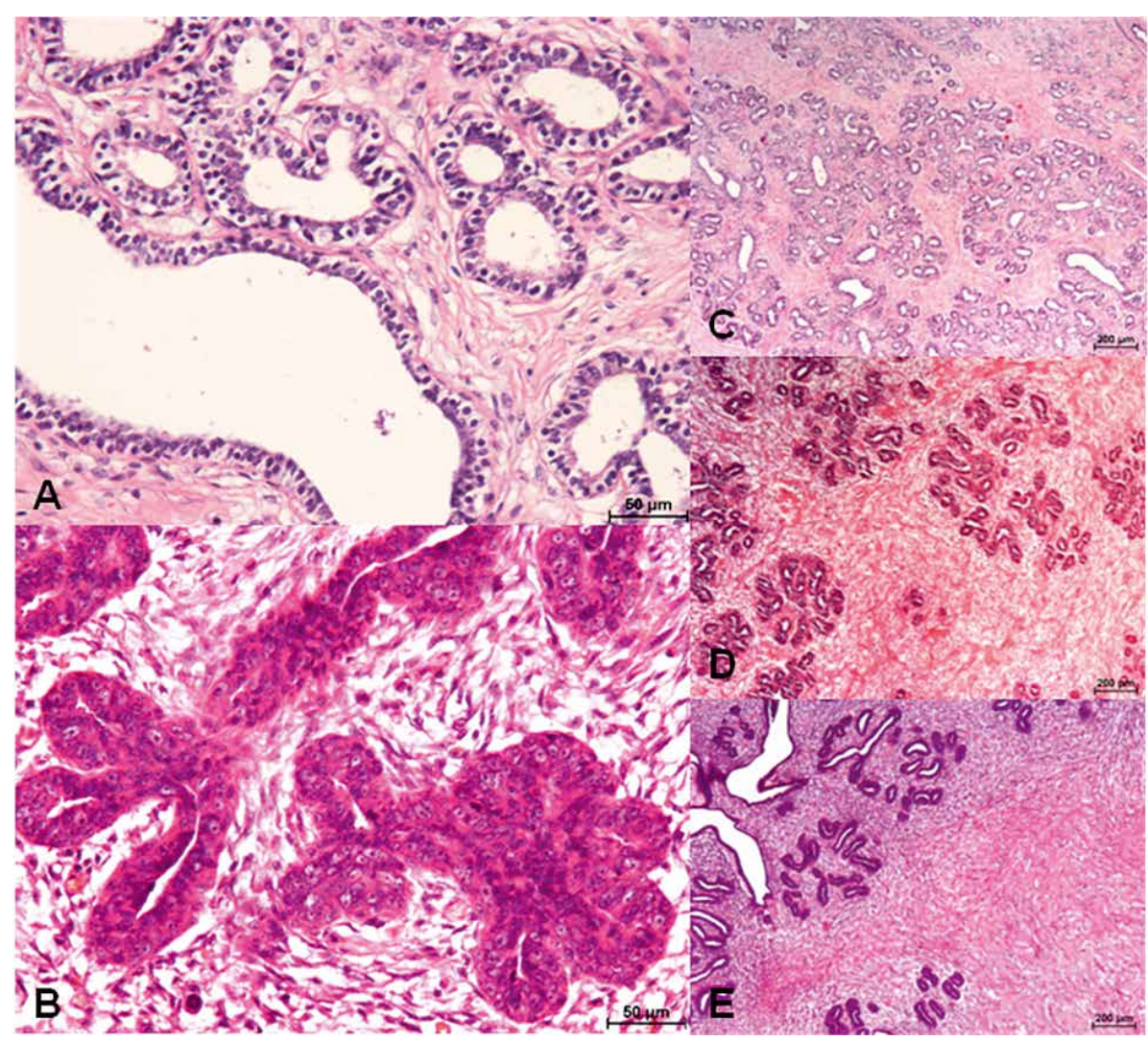

Fig. 1. Differences in microscopic architecture of feline mammary fibroadenomatous change. H\&E staining. A - Tumor with two ductal epithelium layers $(\times 200)$, Bar $=50 \mu \mathrm{m}, \mathrm{B}-$ Tumor with several ductal epithelium layers showing cytological atypia $(\times 200)$. Bar $=50 \mu \mathrm{m}$. Tumors with: poor $(C)$, moderate $(D)$ and abundant (E) cellularity of stroma $(\times 40)$. Bar $=200 \mu \mathrm{m}$ progesterone receptor blockers is a successful therapy of FMFAC $(9,18,35)$.

Immunohistochemistry is most frequently used to evaluate tumor proliferative activity and $\mathrm{Ki}-67$ antigen is the main immunohistochemical marker of a proliferation rate of tumor cells $(8,30)$. There are few studies of Ki-67 antigen expression in feline mammary tumors and benign mammary lesions $(5,16,23,33)$.

The aim of this study was to determine the relationship between histological structure and progesterone receptor expression as well as proliferative activity in feline mammary fibroadenomatous change.

\section{Material and methods}

The material consisted of archived mammary samples obtained from sixteen mammary lesions diagnosed as FMFAC based on their gross and microscopic appearance (24). All the samples submitted to the study were collected from intact female cats, ages ranging from 8 months to 4 years, which had undergone mastectomy in the Department of Animal Reproduction of the University of Life Sciences in Lublin in years 2001 to 2007. Fourteen cats had been given exogenous progestogens for two to four weeks before the mammary lesions developed. In two cases the mammary lesions had developed spontaneously within two weeks after estrus.

For the histological and immunohistochemical examination, representative samples in numbers of one to four,

depending on the size of the lesion, were fixed in $10 \%$ neutral buffered formalin over 24 hours, embedded in paraffin blocks and cut into $4 \mu \mathrm{m}$ thick sections. Routine staining with haematoxylin-eosin (HE) was performed for the histological examination according to the classification recommended for canine and feline mammary tumors (24). The cellularity of stroma was also evaluated.

The lesions were divided into 2 groups based on the number of epithelium layers: nine lesions with a maximum of two ductal epithelium layers formed group A and seven lesions with more than two layers of epithelial cells were assigned to group B (Fig. 1). Moreover, in each group the lesions were classified according to the cellularity of stroma into three subgroups (with poor, moderate and abundant cellularity of stromal fibroblasts). Group A involved two lesions with poor, four lesions with moderate and three lesions with abundant cellularity of stroma, while the group B consisted of three lesions with poor, three lesions with moderate and one lesion with abundant cellularity of stroma.

Paraffin sections on slides covered with $2 \%$ silane solution in acetone at a temperature of $56^{\circ} \mathrm{C}$ were used in the immunohistochemical examinations. The detection of PR expression and proliferative activity in FMFAC lesions was carried out using mouse monoclonal primary antibody against PR (clone 10A9, Immunotech, Marselle, France), diluted $1: 200$ and against Ki-67 antigen (clone MIB-1, Dako, Glostrup, Denmark), diluted $1: 250$, respectively. Sections were deparaffinized in xylene and dehydrated in graded alcohols. In order to unmask the antigenic determi- 
nants, sections were placed in citrate buffer with $\mathrm{pH}=6.0$ and warmed in water bath at temperature of $95^{\circ} \mathrm{C}$ for $20 \mathrm{~min}$ utes in case of PR, while section for $\mathrm{Ki}-67$ detection were kept for 15 minutes in declaoking chamber (Biocare Medical). For immunohistochemical examinations, the system of detection of antigen-antibody complexes was used based on secondary antibodies combined with biotin directed against mouse monoclonal primary antibodies LSAB plus HRP (Dako, Glostrup, Denmark). The enzyme labelling the reaction site was horseradish peroxidase conjugated with streptavidin; tetrahydrochloride-3,-3-diaminobenzidine (DAB) was used as a chromogen (Vector Laboratories, Peterborough, UK). The sections were counterstained with Mayers's haematoxylin. A double control system was employed in the immunohistochemical reactions. For the negative controls, the incubation with a primary antibody was replaced by incubation with mouse IgG serum under the same conditions of the time and temperature. The positive controls were performed on a tissue section obtained from human uterus with immunoreactivity recognised and normal mammary tissue of a queen . Morphometric measurements of immunohistochemically stained tumour sections were performed using the computer image analysis system (NIS-Elements BR-2.20, Laboratory Imaging, Praha, Czech Republic) connected with a light microscope (Nikon Eclipse E-600) and a digital camera (Nikon DS-Fi1). The areas of the strongest protein expression were examined under $40 \times$ magnification. The PR expression was estimated separately for epithelium and stromal cells, using the modified semi-quantitative immunoreaction score (IRS) by Remmele (31), which consists of a 12-point scale (0-12). The score was calculated by multiplying the number reflecting the dominant stain intensity (0 - no detectable stain, 1 - weak nuclear stain, 2-moderate nuclear stain, 3 - strong nuclear stain) by the number reflecting the percentage of these positive tumour cells (0 - no positive cells, $1-<25 \%$ positive cells, $2-25-50 \%$ positive cells, $3-51-75 \%$ positive cells, $4->75 \%$ positive cells). In case of the Ki-67 antigen, an index expressing the percentage of positive cells in 1000 examined cells was calculated.
The results were analysed using Statistica software, version 12.0 (StatSoft, Poland). Values of analysed parameters were characterized using numerousness and percentage or mean, median and standard deviation (SD) values. W Shapiro-Wilk test was used in order to confirm normal distribution of the measurable features. Spearman's rank correlation coefficient was used to evaluate relationship between the variables. In order to determine differences between the compared groups in terms of non-inter-related quality traits chi-square test was used, while for continuous variables the U Mann-Whitney test was performed. Kruskala-Wallis test was used for many groups. A 5\% non sequitur was adapted and $\mathrm{P}$-value of $<0.05$ was considered statistically significant.

\section{Results and discussion}

Although histological examination demonstrated that the number of ductal epithelium layers was higher in lesions with poor and moderate cellularity of stroma than in lesions with abundant cellularity of stroma, no significant differences were found between the groups of lesions (Fig. 2).

A positive reaction for the presence of $P R$ and Ki-67 antigen was observed in the nuclei of ductal

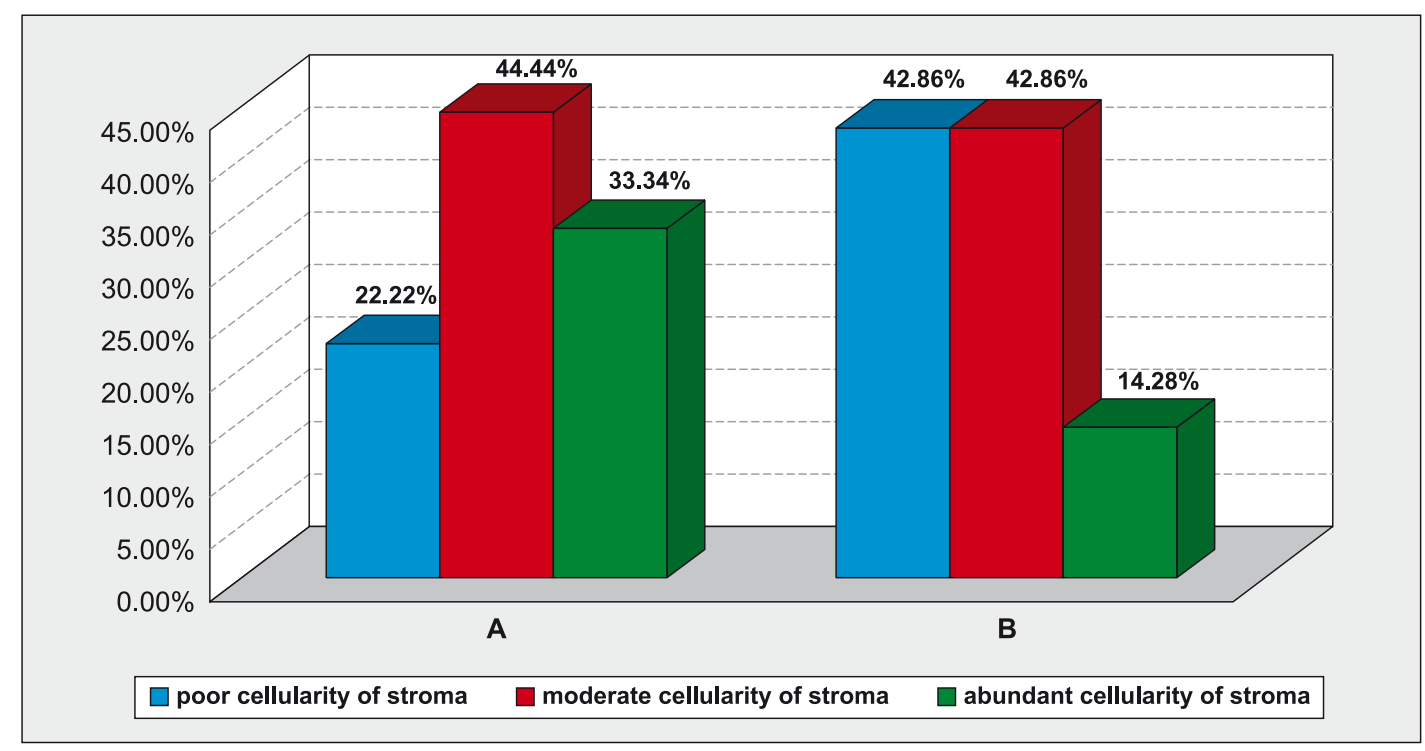

Fig. 2. Relationship between the number of ductal epithelium layers and the cellularity of stroma in feline mammary fibroadenomatous change

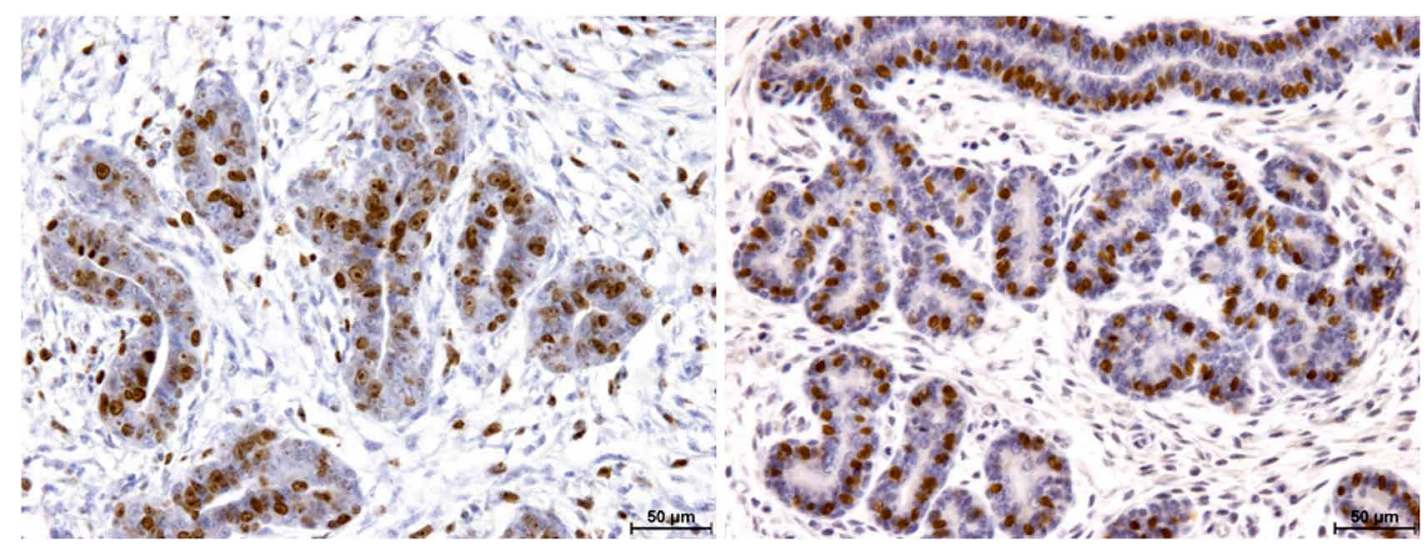

Fig. 3. PR expression (A) and Ki-67 antigen expression (B) in feline mammary fibroadenomatous change. Immunohistochemical staining LSAB plus, HRP $(\times 200)$. Bar $=50 \mu$ 


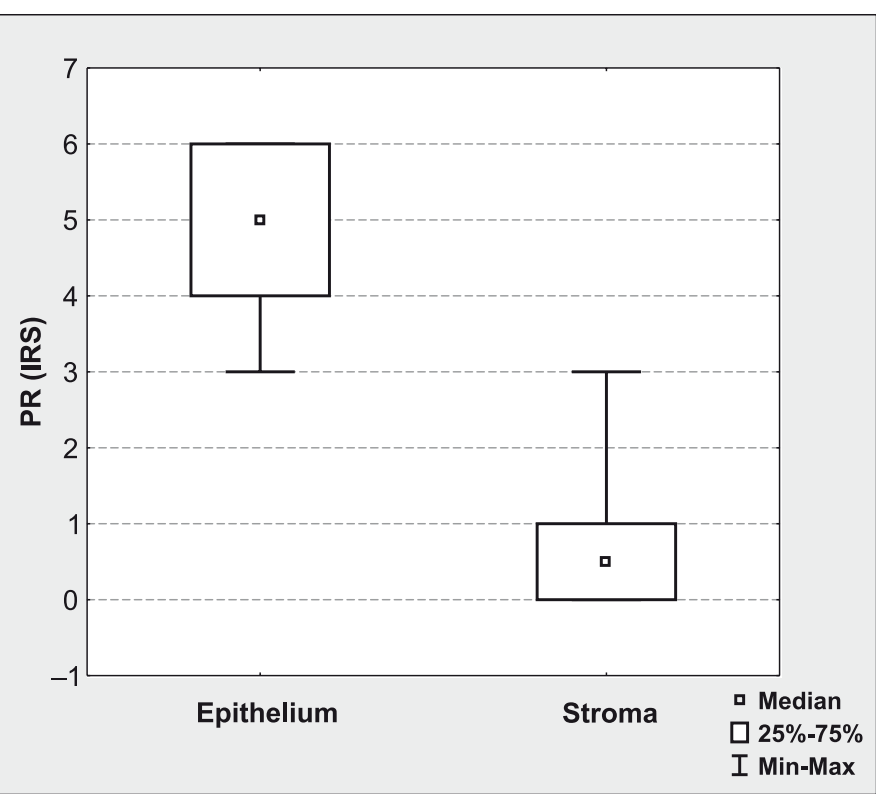

Fig. 4. Relationship between PR expression in epithelial and stromal cells according to IRS in all studied tumors

epithelial cells of all examined lesions. In relation to stromal cells, a negative reaction was found in case of PR (eight lesions). The nuclear immunohistochemical reaction for the presence of PR and $\mathrm{Ki}-67$ antigen showed a granular-diffuse pattern of staining. The reaction intensity in case of PR differs from weak to strong, while in case of Ki-67 antigen it was similar in all positively reacting cells (Fig. 3).

PR expression showed a significantly higher level of expression $(\mathrm{P}=0.0001)$ in the epithelial cells (median IRS $=5.00)$ as compared to stromal cells (median IRS $=0.50)$ (Fig. 4). Similarly, the proliferative index, estimated from Ki-67 labelling was significantly higher $(\mathrm{P}=0.010)$, in epithelial cells (median Ki-67 = 29.95\%) than in stromal cells (median Ki-67 $=18.00 \%$ ) (Fig. 5).

In group $A$ the values of PR expression in epithelial cells, estimated according to the Remmele scoring system, ranged from 4 to 6 points. In group B the PR expression ranged from 3 to 6 points. The expression of PR in stromal cells was weaker compared with epithelial cells and ranged from 0 to 3 points in group $\mathrm{A}$ and from 0 to 1 point in group B.

The proliferative index values in epithelial cells in groups A and B ranged from $23.8 \%$ to $40.5 \%$ and from $19.9 \%$ to $43.2 \%$ respectively. Analyzing the expression of Ki-67 antigen in stromal cells of lesions belonging to groups A and B we found that the values of Ki-67 antigen index ranged from $4 \%$ to $55 \%$ in group $\mathrm{A}$ and from $2 \%$ to $40 \%$ in group B. No significant differences or correlations were found concerning PR and Ki-67 antigen expression between the groups (Tab. 1).

The aim of present study was to establish the relationship between histological structure, PR expression and proliferative activity in FMFAC in female cats. The fibroadenomatous changes in feline mammary glands have a characteristic microscopic appearance. It is composed of branching, epithelial-lined, ductal

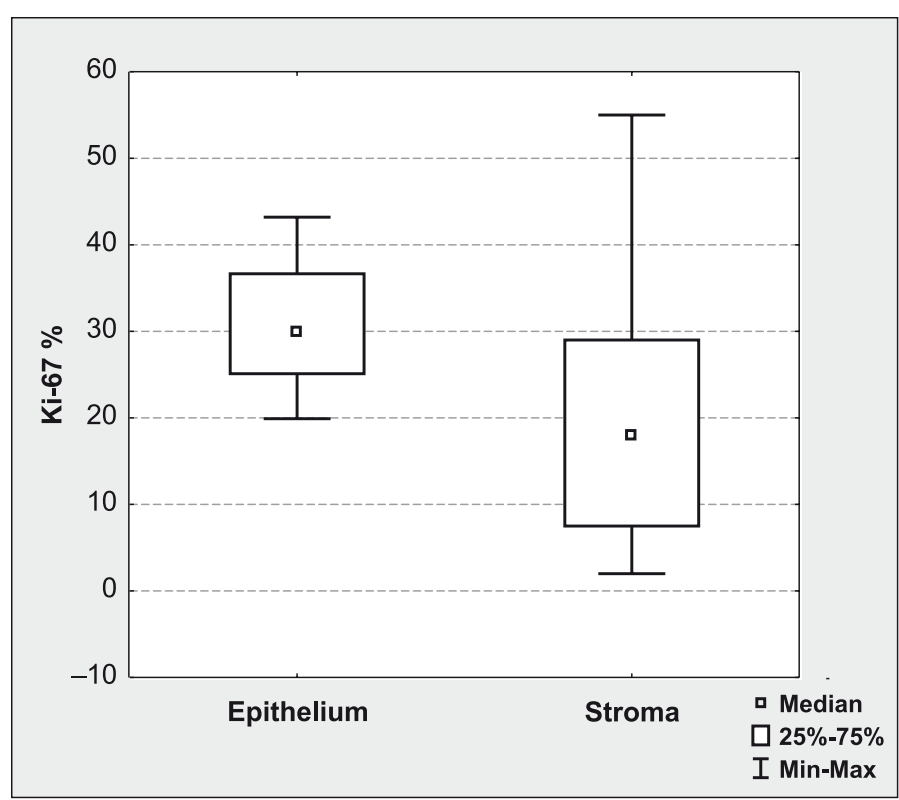

Fig. 5. Relationship between Ki-67 antigen expression in epithelial and stromal cells in all studied tumors

structures that extend into actively proliferating connective tissue in a lobular arrangement (1). Previous studies suggest that the proportions of ductal epithelial and periductal connective tissue are variable in this mammary lesion and that the ductal structures are lined by several layers of epithelial cells $(1,27)$. Our study confirmed various amounts of stromal cells and diverse number of ductal epithelium cell layers in the fibroadenomatous change in feline mammary gland. Moreover, we observed that the number of layers of ductal epithelial cells was higher in tumors with poor and moderate cellularity of stroma than in tumors with abundant cellularity of stroma, although, significant difference was not found.

It is well known that the development and growth of the mammary gland is under the control of progesterone, which acts through the PRs on stromal and epithelial cells (4). It is thought that the interaction of progesterone and synthetic progestogens with PRs stimulates local production of growth hormone and insulin-like growth factors, which possess a strong mitogenic effect

Tab. 1. Comparison of PR and Ki-67 antigen expression between groups A and B

\begin{tabular}{|c|c|c|c|c|c|}
\hline \multirow{2}{*}{\multicolumn{2}{|c|}{ Parameter }} & \multicolumn{2}{|c|}{ PR (IRS) } & \multicolumn{2}{|c|}{ Ki-67 (\%) } \\
\hline & & \multirow{2}{*}{$\begin{array}{c}\text { epithelium } \\
4-6\end{array}$} & \multirow{2}{*}{$\begin{array}{c}\text { stroma } \\
0-3\end{array}$} & \multirow{2}{*}{$\begin{array}{l}\text { epithelium } \\
23.8-40.5\end{array}$} & \multirow{2}{*}{$\begin{array}{c}\text { stroma } \\
4-55\end{array}$} \\
\hline A & Range & & & & \\
\hline & Mean & 5.11 & 1.00 & 30.70 & 22.56 \\
\hline & Median & 6.00 & 1.00 & 28.90 & 19.00 \\
\hline & SD & 1.05 & 1.12 & 6.59 & 15.01 \\
\hline \multirow[t]{4}{*}{ B } & Range & $3-6$ & $0-1$ & $19.9-43.2$ & $2-40$ \\
\hline & Mean & 4.71 & 0.43 & 31.43 & 16.86 \\
\hline & Median & 4.00 & 0.00 & 33.40 & 9.00 \\
\hline & SD & 1.25 & 0.53 & 7.72 & 15.44 \\
\hline \multicolumn{2}{|c|}{$P$ value } & 0.56 & 0.40 & 0.92 & 0.46 \\
\hline
\end{tabular}


on mammary tissue $(25,28)$. Disturbed response to progesterone stimulation may lead to mammary gland hyperplastic or neoplastic growth (32). It is also known that the expression of PR is higher in benign canine and feline mammary tumors than in malignant ones $(6,22,32)$. It was demonstrated that the expression of PR was significantly higher in FMFAC than in normal mammary tissue (22). Our study showed expression of PR in the nuclei of ductal epithelial cells in all examined lesions and in the nuclei of stromal cells in 50\% of the lesions. There was no correlation between the histological structure of lesions and the PR expression. In a previous study, Millanta et al. (22) found that the immunostaining for PR was localized in the nuclei of normal, dysplastic (involving FMFAC) and neoplastic epithelial cells and, sometimes, in stromal cells. Mol et al. (26) showed two PR isoforms (A and B) in tissue samples from FMFAC, with predominant expression in ductal epithelium. Wehrend et al. (35) reported that the mean percentage of the PR-expressing epithelial cells of glandular ducts was $78.2 \%$. In our study, the PR expression estimated according to the Remmele scoring system was significantly higher in epithelial cells than in stromal cells; however, the differences in PR expression in ductal epithelium and stromal cells between studied groups were not significant. Due to progesterone dependence, FMFAC can be treated by the elimination of the source or action of progestins. Previous studies describe ovariectomy as a treatment method, leading to regression of the mammary tissue within three to four weeks (15). However, this method was inefficient when the condition developed as a result of the exogenous administration of progestagens for estrus prevention, behavioral modification and certain dermatologic conditions. Nowadays, FMFAC can be treated successfully with the progesterone receptor blocker aglepristone $(9,18,35)$. Therapeutic mechanism of aglepristone is based on antagonistic binding to the intracellular progesterone receptor (3, 10). Our findings demonstrating the high percentage of PR-expressing cells in the duct epithelium and presence of PR-positive cells with a lower level of expression in the stroma may explain such a high efficacy of this treatment.

It is known that proliferative activity is higher in malignant mammary tumors than in benign ones (5, 22). Despite that FMFAC is classified as a hyperplastic lesion, with favorable biological behavior, all cases of this condition exhibit a high rate of cell proliferation, with mean values similar to those of carcinomas $(5,23)$. In contrast to other feline mammary lesions, where cell proliferation is largely restricted to the epithelial cells, in fibroadenomatous change the high proliferative activity involves both epithelial and stromal components (5). In the present study, proliferative activity in FMFAC lesions was evaluated by measuring Ki-67 antigen expression. This is the main immunohistochemical marker used to evaluate tumor proliferative activity, but data on its use to examine FMFAC proliferative activity are scarce. Dias Pereira et al. (5) and Millanta et al. (22) reported that the rate of proliferation, measured based on the expression of Ki-67 antigen, was significantly higher in cases of feline fibradenomatous change than in normal or dysplastic tissues and non-invasive carcinomas. We found that FMFAC exhibits a high rate of proliferation and that the proliferative activity was higher in ductal epithelial cells than in stromal cells. Nonetheless, the differences between the two studied groups varying in the thickness of the epithelium were not statistically significant. This agrees with studies of other authors indicating that the mitotic figures are commonly present both in epithelium and stroma $(1,27)$. In turn, the study by Dias Pereira et al. (5) revealed that the proliferative activity (measured by Ki-67 antigen index) was higher in epithelial cells of glandular ducts than in stromal cells of feline fibroadenomatous change; however, significant difference was not found.

In conclusion, the results of this study indicate that the rate of proliferation and the expression of PR in epithelial cells are higher than in stromal cells. There is no relationship between histological architecture, PR expression and proliferative activity in FMFAC. This confirms that FMFAC is uniform in terms of PR expression and may explain the regression of enlarged mammary gland after administration of progesterone receptor blockers in most cases.

\section{References}

1. Allen H. L.: Feline mammary hypertrophy. Vet. Pathol. 1973, 10, 501-508.

2. Burstyn $U .:$ Management of mastitis and abscessation of mammary glands secondary to fibroadenomatous hyperplasia in a primiparturient cat. J. Am. Vet. Med. Assoc. 2010, 236, 326-329.

3. Cadepond F., Ulmann A., Baulieu E. E.: RU 486 (mifepristone): mechanisms of action and clinical uses. Annu. Rev. Med. 1997, 48, 129-159.

4. Connelly O. M., Mulac-Jericevic B., Lydon J. P.: Progesterone-dependent regulation of female reproductive activity by two distinct progesterone receptor isoforms. Steroids 2003, 68, 771-778.

5. Dias Pereira P., Carvalheira J., Gärtner F.: Cell proliferation in feline normal, hyperplastic and neoplastic mammary tissue - an immunohistochemical study. Vet. J. 2004, 168, 180-185.

6. Donnay I., Raü̈s J., Devleeschouwer N., Wouters-Ballman P., Leclercq G., Verstegen J.: Comparison of estrogen and progesterone receptor expression in normal and tumor mammary tissues from dogs. Am. J. Vet. Res. 1995, 56, 1188-1194.

7. Goldschmidt M., Peña L., Rasotto R., Zappulli V.: Classification and grading of canine mammary tumors. Vet. Pathol. 2011, 48, 117-131.

8. Goodson W. H., Moore D. H., Ljung B. M., Chew K., Mayall B., Smith H. S., Waldman F. M.: The prognostic value of proliferation indices: a study with in vivo bromodeoxyuridine and Ki-67. Breast Cancer Research and Treatment. 2000, 59, 113-123.

9. Görlinger S., Kooistra H. S., Broek A. van den, Okkens A. C.: Treatment of fibroadenomatous hyperplasia in cats with aglepristone. J. Vet. Intern. Med. 2002, 16, 710-713.

10. Guil-Luna S., Sanchez-Cespedes R., Millan Y., De Andres F. J., Rollon E., Domingo V., Guscetti F., Martin de las Mulas J.: Algepristone decreases proliferation in progesterone receptor-positive canine mammary carcinomas. J. Vet. Inter. Med. 2011, 25, 518-523.

11. Guray M., Sahin A. A.: Benign breast diseases: classification, diagnosis, and management. Oncologist. 2006, 11, 435-449.

12. Hayden D. W., Barnes D. M., Johnson K. H.: Morphologic changes in the mammary gland of megestrol acetate-treated and untreated cats: a retrospective study. Vet. Pathol. 1989, 26, 104-113. 
13. Hayden D. W., Johnson K. H., Ghobrial H. K.: Ultrastructure of feline mammary hypertrophy. Vet. Pathol. 1983, 20, 254-264.

14. Hayden D. W., Johnston S. D., Kiang D. T., Johnson K. H., Barnes D. M.: Feline mammary hyperthrophy/fidroadenoma complex: clinical and hormonal aspects. Am. J. Vet. Res. 1981, 42, 1699-1703.

15. Hinton M., Gaskell C. J.: Non-neoplastic mammary hypertrophy in the cat associated either with pregnancy or with oral progestagen therapy. Vet. Rec. 1977, 100, 277-280.

16. Hughes K., Dobson J. M.: Prognostic histopathological and molecular markers in feline mammary neoplasia. Vet. J. 2012, 194, 19-26.

17. Jelinek F., Barton R., Posekana J., Hasonova L.: Gynaecomastia in a tom-cat caused by cyproterone acetate: a case raport. Vet. Med. 2007, 52, 521-525.

18. Jurka P., Max A.: Treatment of fibroadenomatosis in 14 cats with aglepristone - changes in blood parameters and follow-up. Vet. Rec. 2009, 165, 657-660.

19. Krimer P. M., Harvey S. B., Blas-Machado U., Lauderdale J. D., Moore P. A.: Reversible fibroadenomatous mammary hyperplasia in male and female New Zealand white rabbits associated with cyclosporine A administration. Vet. Pathol. 2009, 46, 1144-1148.

20. Loretti A. P., Ilha M. R. S., Breitsameter I., Faraco C. S.: Clinical and pathological study of feline mammary fibroadenomatous change associated with depot medroxyprogesterone acetate therapy. Arq. Bras. Med. Vet. Zootec. 2004, 56, 270-274

21. MacDougall L. D.: Mammary fibroadenomatous hyperplasia in a young cat attributed to treatment with megestrol acetate. Can. Vet. J. 2003, 44, 227-229.

22. Millanta F., Calandrella M., Vannozzi I., Poli A.: Steroid hormone receptors in normal, dysplastic and neoplastic feline mammary tissues and their prognostic significance. Vet. Rec. 2006, 158, 821-824.

23. Millanta F., Lazzeri G., Mazzei M., Vannozzi I., Poli A.: MIB-1 labelling index in feline dysplastic and neoplastic mammary lesions and its relationship with postsurgical prognosis. Vet. Pathol. 2002, 39, 120-126.

24. Misdorp E., Else R. W., Hellmén E., Lipscomb T. P.: Histological classification of mammary tumours of the dog and cat. Second series. WHO international histological classification of tumors of domestic animals. Washington DC, Armed Forces Institute of Pathology. Vol. VII, 1999.

25. Mol J. A., Garderen E. van, Rutteman G. R., Rijnberk A.: New insights in the molecular mechanism of progestin-induced proliferation of mammary epithelium: induction of the local biosynthesis of growth hormone $(\mathrm{GH})$ in the mammary gland of dogs, cats and humans. J. Steroid Biochem. Molec. Biol. 1996, 57, 67-71.

26. Mol J. A., Gracanin A., Gier J. de, Rao N., Schaefers-Okkens A., Rutteman G. R., Kooistra H.: Molecular genetics and biology of progesterone signaling in mammary neoplasia. Proc. of the joint meeting of the $7^{\text {th }}$ International Symposium on Canine and Feline Reproduction and the $15^{\text {th }}$ Congress of the European Veterinary Society for Small Animal Reproduction. British Columbia 2012, p. 107-108.

27. Mulas J. M. de las, Millán Y., Bautista M. J., Pérez J., Carrasco L.: Ostrogen and progesterone receptors in feline fibroadenomatous change: an immunohistochemical study. Res. Vet. Sci. 2000, 68, 15-21.

28. Ordás J., Millán Y., Monteros A. E. de los, Reymundo C., Mulas J. M. de las Immunohistochemical expression of progesterone receptors, growth hormone and insulin growth factor-I in feline fibroadenomatous change. Res. Vet. Sci. 2004, 76, 227-233.

29. Ozenc E., Bozkurt M. F.: Atypical fibroepithelial hyperplasia of the teats in a Sphynx cat: a case report. Vet. Med. 2014, 59, 265-269.

30. Peña L. L., Nieto A. I., Pérez-Alenza M. D., Cuesta P., Castaño M.: Immunohistochemical detection of $\mathrm{Ki}-67$ and PCNA in canine mammary tumors: relationship to clinical and pathologic variables. J. Vet. Diagn. Invest. 1998, 10, 237-246.

31. Remmele W., Stegner H. E.: Recommendation for uniform definition of an immunoreactive score (IRS) for immunohistochemical estrogen receptor detection (ER-ICA) in breast cancer tissue. Pathologe. 1987, 8, 138-140.

32. Rutteman G. R., Misdorp W.: Hormonal background of canine and feline mammary tumours. J. Reprod. Fertil. 1993, 47 (Supp.), 483-487.

33. Seixas F., Palmeira C., Pires M. A., Bento M. J., Lopes C.: Grade is an independent prognostic factor for feline mammary carcinomas: a clinicopathological and survival analysis. Vet. J. 2011, 187, 65-71.

34. Szczubiał M., Łopuszyński W.: Włókniakogruczolak gruczołu mlekowego u jednorocznej kotki. Magazyn Wet. 1997, 6, 358-359.

35. Wehrend A., Hospes R., Gruber A. D.: Treatment of feline mammary fibroadenomatous hyperplasia with a progesterone-antagonist. Vet. Rec. 2001, $148,346-347$.

Corresponding author: Vet. surg. Magdalena Krawczyk, ul. Popiełuszki 36/16, 20-052 Lublin; e-mail: magdalenakrawczyk16@yahoo.com 